\title{
FAKTOR - FAKTOR YANG BERHUBUNGAN DENGAN PENGETAHUAN BIDAN TENTANG PENULARAN HIV/AIDS PADA PROSES PERSALINAN DI RUMAH SAKIT UMUM PUSAT H. ADAM MALIK MEDAN
}

\author{
Suswati \\ Jurusan Kebidanan Poltekkes Kemenkes Medan
}

\begin{abstract}
Abstrak
Bidan merupakan salah satu resiko tertinggi tertularnya HIV/AIDS, apabila tidak memahami bagaimana cara penanggulangan HIV/AIDS dan kewaspadaan universal yang merupakan upaya untuk mencegah kemungkinan terjadinnya penularan infeksi. Di Sumatera Utara terdapat 3 orang bidan yang terinfeksi HIV/AIDS pada saat menolong proses persalinan. Penelitian ini bertujuan untuk mengetahui faktor - faktor yang berhubungan dengan pengetahuan bidan tentang penularan HIV/AIDS pada proses persalinan. Penelitian ini bersifat analitik, populasi penelitian ini adalah seluruh bidan yang bekerja di Rumah Sakit Umum Pusat H.Adam Malik Medan berjumlah 54 orang, dan seluruhnya dijadikan sampel.Teknik analisis yang digunakan adalah analisis univariat dan analisis bivariat dengan menggunakan uji chi-square. Dari hasil penelitian ini yang diperoleh bahwa mayoritas bidan berumur $>35$ tahun $(79,6 \%)$, pendidikan D-III $(68,5 \%)$, lama bekerja > 10 tahun (81,5\%). Dari hasil uji chi-square tidak ada hubungan yang signifikan antara variabel umur,pendidikan dan lama bekerja dengan tingkat pengetahuan bidan. Berdasarkan penelitian mayoritas bidan berpengetahuan kurang tentang penularan HIV/AIDS pada proses persalinan. Hal ini disebabkan karena bidan kurang mendapatkan informasi tentang penularan HIV/AIDS pada proses persalinan, sehingga diskriminasi terhadap orang dengan HIV/IADS terjadi khususnya pada ibu yang akan bersalin.
\end{abstract}

Kata Kunci : Pengetahuan,Bidan,Penularan HIV/AIDS, Persalinan

\section{PENDAHULUAN}

Human Immunodeficiency Virus (HIV) merupakan virus yang menyerang sistem kekebalan tubuh manusia dan kemudian akan menimbulkan AIDS (Acquired Immuno Deficiency Syndrom). (Zein, 2007).

Menurut World Health Organization (WHO) pada tahun 2007 ada 33,2 juta orang yang hidup dengan HIV tercatat 2,5 juta adalah baru terinfeksi. Di Asia jumlah penderita HIV meningkat lebih dari 100\%.Dan Indonesia adalah salah satu Negara dengan pertumbuhan epidemi HIV tercepat. (Departemen Kesehatan RI, 2009).

Sejak tahun 2007, indonesia sudah dikategorikan sebagai Negara yang berada dalam tahap dari "Epidemi rendah menjadi Epidemi terkonsentrasi HIV/AIDS" yaitu suatu keadaan yang mengindikasikan bahwa tingkat penularan HIV/AIDS sudah cukup tinggi pada populasi beresiko tinggi.

Pada kasus HIV/AIDS cara penularan terbanyak melalui hubungan seksual $(51,3 \%)$, inject Drug User atau IDU $(39,6 \%)$, transfusi darah $(3,1 \%)$ dan penularan dari ibu ke bayi $(2,6 \%)$ (Maryunani, 2009).

Dari data Kementrian Kesehatan Republik Indonesia, pada akhir 2010 dilaporkan kasus tertinggi tertularnya HIV/AIDS yaitu pada kelompok usia produktif 20 - 29 tahun $(47,2 \%)$, kelompok umur $30-$
39 tahun $(31,3 \%)$ dan kelompok umur 40 - 49 tahun $(9,5 \%)$. Dan kelompok termuda yaitu kelompok umur 15 - 20 tahun (2\%), kelompok umur $1-5$ tahun (1\%) dan kelompok umur dibawah 1 tahun (2\%) (Profil Kesehatan Indonesia, 2011).

Mayoritas orang yang terinfeksi HIV berada pada usia reproduksi aktif, maka diperkirakan jumlah kehamilan dengan HIV - positif akan meningkat di Indonesia. Wanita yang sudah terinfeksi HIV/AIDS akan berpotensial menularkan virus HIV/AIDS kepada bayinya. Oleh karena itu, bidan maupun perawat perlu mengetahui bagaimana pencegahan dan penatalaksanaan penularan HIV dari ibu ke bayi. Resiko bayi yang terinfeksi pada saat kehamilan berkisar 7\%, pada proses kelahiran $15 \%$ dan penularan melalui Air Susu Ibu yaitu sebesar 13\% (Maryunani,2009).

Bidan mempunyai resiko tinggi untuk tertular HIV/AIDS, apabila tidak memahami bagaimana cara penanggulanganHIV/AIDS, kewaspadaan universal (kewaspadaan yang dilakukan secara menyeluruh) yang merupakan suatu upaya untuk mencegah kemungkinan terjadinya penularan infeksi. Untuk itu, prosedur tetap penggunaan alat - alat kesehatan yang digunakan secara berulang, perlu dipahami secara benar sehingga kemungkinan terjadinya penularan penyakit menular tidak akan terjadi. Pelatihan mengenai kewaspadaan universal 
merupakan hal yang sangat penting, karena pelatihan ini dapat memberikan peningkatan ilmu pengetahuan dan kewaspadaan bidan dalam menjalankan tugasnya agar terlindung dari tertularnya penyakit HIV/AIDS (Hurek,2008).

Hasil survey terpadu dari 2616 kasus HIV/AIDS yang terjadi di Sumatera Utara, Medan menduduki peringkat pertama dengan jumlah 1081 kasus HIV dan 1535 kasus AIDS. Selaras Dengan target pencapaian Millenium Development Goals (MDGs) 2015, Depkes telah mematokkan target untuk membalikkan penyebaran HIV/AIDS (Profil Kesehatan Indonesia, 2011).

Dari data survey awal yang diperoleh pada tahun 2011 di Pusat Pelayanan Khusus (Pusyansus) Voluntary Counseling And Testing (VCT) Rumah Sakit Umum Pusat H. Adam Malik Medan menemukan sebanyak 36 kasus kehamilan dengan HIV/AIDS (Pusyansus RSUP HAM,2011).

Kasus HIV/AIDS juga telah menyerang bidan.Di Sumatera Utara terdapat 3 orang bidan yang terinfeksi HIV/AIDS karena membantu ibu yang sedang melahirkan. Menurut jamluddin (2009), penularan ini terjadi pada saat proses pertolongan persalinan, dimana mereka tidak menyiapkan perlengkapan yang telah ditentukan.

\section{RUMUSAN MASALAH}

Berdasarkan uraian diatas, maka yang menjadi rumusan masalah adalah apa faktor - faktor yang berhubungan dengan pengetahuan bidan tentang penularan HIV/AIDS dalam proses persalinan di Rumah Sakit Umum Pusat Haji Adam Malik Medan Tahun 2013.

\section{TUJUAN PENELITIAN}

Untuk mengetahui faktor - faktor yang berhubungan dengan pengetahuan bidan tentang penularan HIV/AIDS pada proses persalinan

\section{MANFAAT PENELITIAN}

1. Untuk menambah wawasan kepada petugas kesehatan dalam menjaga kewaspadaan dalam perlindungan diri terhadap penularan HIV/AIDS khususnya pada saat proses persalinan.

2. Hasil penelitian ini diharapkan dapat menjadi masukan pada Rumah Sakit sebagai bahan acuan dalam menyusun kebijakan di masa yang akan datang serta pelaksanaan program pelayanan kesehatan khususnya pada pasien yang tertular HIV/AIDS.

\section{METODE PENELITIAN}

\footnotetext{
Jenis Penelitian

Jenis penelitian ini bersifat analitik dengan desain "cross sectional".
}

\section{Lokasi dan Waktu Penelitian \\ Lokasi Penelitian}

Lokasi penelitian ini di lakukan di Wilayah Kerja Rumah Sakit Umum Pusat Haji Adam Malik Medan

\section{Waktu Penelitian}

Waktu penelitian yang dilakukan pada bulan Pebruari2013 sampai dengan bulan Juni Tahun 2013.

\section{Populasi dan Sampel \\ Populasi}

Populasi dalam penelitian ini adalah semua bidan yang bekerja di Rumah Sakit Umum Pusat Haji Adam Malik Medan tahun 2013 yaitu sebanyak 54 orang.

Sampel

Sampel dalam penelitian ini yang digunakan adalah semua bidan yang bekerja di RSUP H.Adam Malik Medan Tahun 2013 yaitu sebanyak 54 orang.

\section{HASIL DAN PEMBAHASAN}

Analisis Univariat

Tabel 1. Distribusi Responden Berdasarkan PengetahuanDi RSUP H.Adam Malik Medan Tahun 2013

\begin{tabular}{llll}
\hline No & Pengetahuan & Jumlah & $\mathbf{( \% )}$ \\
\hline 1. & Baik & 24 & 44,4 \\
2. & Kurang & 30 & 55,6 \\
\hline & Jumlah & $\mathbf{5 4}$ & $\mathbf{1 0 0}$ \\
\hline
\end{tabular}

Berdasarkan tabel 1 mayoritas bidan yang bekerja di RSUP H.Adam Malik Medan adalah berpengetahuan kurang sebanyak 30 orang $(55,6 \%)$ dan minoritas berpengetahuan baik sebanyak 24 orang $(44,4 \%)$.

Umur

Umur bidan yang bekerja di Rumah Sakit Umum Pusat H.Adam Malik Medan Tahun 2013, dapat dikelompokkan pada umur > 35 tahun dan umur $25-$ 35 tahun.

Tabel 2. Distribusi Responden Berdasarkan UmurDi RSUP H.Adam Malik Medan Tahun 2013

\begin{tabular}{llll}
\hline No. & Umur & $\begin{array}{l}\text { Jumlah } \\
\text { (Orang) }\end{array}$ & $\mathbf{( \% )}$ \\
\hline 1. & $>$ 35 Tahun & 43 & 79,6 \\
2. & 25 - 35 Tahun & 11 & 20,4 \\
\hline & Jumlah & $\mathbf{5 4}$ & $\mathbf{1 0 0}$ \\
\hline
\end{tabular}

Berdasarkan Tabel 2 terlihat bahwa mayoritas umur bidan yang bekerja di Rumah Sakit Umum Pusat H.Adam Malik Medan yaitu berumur >35 tahun sebanyak 43 orang $(79,6 \%)$ dan minoritas berumur antara 25 - 35 tahun sebanyak 11 orang $(20,4 \%)$. 


\section{Pendidikan}

Pendidikan bidan yang bekerja Di Rumah Sakit Umum Pusat H.Adam Malik Medan Tahun 2013 yaitu dikelompokkan menjadi Bidan D-III dan Bidan D-I yang dapat diuraikan sebagai berikut :

Tabel 3. Distribusi Responden Berdasarkan Pendidikan Di RSUP H.Adam Malik Medan Tahun 2013

\begin{tabular}{llll}
\hline No & Pendidikan & $\begin{array}{l}\text { Jumlah } \\
\text { (Orang) }\end{array}$ & $\mathbf{( \% )}$ \\
\hline 1. & D - III & 37 & 68,5 \\
2. & D - I & 17 & 31,5 \\
\hline & Jumlah & $\mathbf{5 4}$ & $\mathbf{1 0 0}$ \\
\hline
\end{tabular}

Berdasarkan tabel 3 terlihat bahwa mayoritas bidan yang berada di Rumah Sakit Umum Pusat H.Adam Malik Medan adalah dengan berpendidikan D - III yaitu sebanyak 37 orang $(68,5 \%)$ dan minoritas bidan yang berpendidikan D - I yaitu sebanyak 17 orang $(31,5 \%)$.

\section{Lama Bekerja}

Lama bekerja bidan di Rumah Sakit Umum Pusat H.Adam Malik Medan tahun 2013, dapat dikelompokkan > 10 tahun dan antara 5-10 tahun yang dapat diuraikan sebagai berikut :

Tabel 4.Distribusi Responden Berdasarkan Lama BekerjaDi RSUP H.Adam Malik MedanTahun 2013

\begin{tabular}{llll}
\hline No. & Lama Bekerja & $\begin{array}{l}\text { Jumlah } \\
\text { (Orang) }\end{array}$ & $\mathbf{( \% )}$ \\
\hline 1. & $>$ 10 Tahun & 44 & 81,5 \\
2. & 5 - 10 Tahun & 10 & 18,5 \\
\hline & Jumlah & $\mathbf{5 4}$ & $\mathbf{1 0 0}$ \\
\hline
\end{tabular}

Berdasarkan Tabel 4 bahwa mayoritas lama bekerja bidan yaitu lebih dari 10 tahun sebanyak 44 orang $(81,5 \%)$ dan minoritas lama bekerja bidan yaitu antara $5-10$ tahun sebanyak 10 orang $(18,5 \%)$.

\section{Analisa Bivariat}

Hubungan umur dengan pengetahuan bidan tentang penularan HIV/AIDS pada proses persalinan dapat dilihat pada tabel berikut ini:

Tabel 5. Distribusi Umur Berdasarkan Tingkat Pengetahuan Bidan Tentang Penularan HIV/AIDS Pada Proses Persalinan Di RSUP Haji Adam Malik Medan Tahun 2013

\begin{tabular}{|c|c|c|c|c|c|c|c|c|}
\hline \multirow{3}{*}{ No } & \multirow{3}{*}{ Umur } & \multicolumn{6}{|c|}{ Pengetahuan } & \multirow{3}{*}{$P$} \\
\hline & & \multicolumn{2}{|c|}{ Baik } & \multicolumn{2}{|c|}{ Kurang } & \multirow[b]{2}{*}{$\mathbf{F}$} & \multirow[b]{2}{*}{$\%$} & \\
\hline & & $\mathbf{F}$ & $\%$ & $\mathbf{F}$ & $\%$ & & & \\
\hline 1. & $>35$ Tahun & 19 & 44,2 & 24 & 55,8 & 43 & 100 & \multirow{3}{*}{0,94} \\
\hline 2. & $25-35$ Tahun & 5 & 45,5 & 6 & 54,5 & 11 & 100 & \\
\hline Jun & nlah & 24 & 44,4 & 30 & 55,6 & 54 & 100 & \\
\hline
\end{tabular}

Berdasarkan tabel 5 mayoritas bidan berumur $>35$ tahun dengan rata - rata tingkat pengetahuan kurang tentang penularan HIV/AIDS pada proses persalinan sebanyak $(55,8 \%)$.

Dari hasil uji Chi-square didapat nilai $p(0,94)>$ 0,05 , ini berarti tidak ada hubungan yang signifikan antara umur dengan tingkat pengetahuan.

Hubungan Pendidikan Dengan Pengetahuan Bidan Tentang Penularan HIV/AIISS Pada Proses Persalinan Hubungan pendidikan dengan pengetahuan bidan tentang penularan HIV/AIDS pada proses persalinan dapat dilihat pada tabel sebagai berikut:

Tabel 6.Distribusi Pendidikan Berdasarkan Tingkat Pengetahuan Bidan Tentang Penularan HIV/AIDS Pada Proses Persalinan Di RSUP Haji Adam Malik Medan Tahun 2013

\begin{tabular}{|c|c|c|c|c|c|c|c|c|}
\hline \multirow{3}{*}{ No } & & \multicolumn{4}{|c|}{ Pengetahuan } & \multirow{2}{*}{\multicolumn{2}{|c|}{-Total }} & \multirow{3}{*}{$P$} \\
\hline & \multirow{2}{*}{ Pendidikan } & \multicolumn{2}{|c|}{ Baik } & \multicolumn{2}{|c|}{ Kurang } & & & \\
\hline & & $\overline{\mathbf{F}}$ & $\%$ & $\mathbf{F}$ & $\%$ & $\mathbf{F}$ & $\%$ & \\
\hline 1. & $\mathrm{D}-\mathrm{III}$ & 18 & 48,6 & 19 & 51,4 & 37 & 100 & \\
\hline 2. & D - I & 6 & 35,3 & 11 & 64,7 & 17 & 100 & \\
\hline$\overline{\text { Jun }}$ & nlah & 24 & 44,4 & 30 & 55,6 & 54 & 100 & \\
\hline
\end{tabular}

Berdasarkan Tabel 6 terdapat mayoritas bidan yang bekerja di RSUP H.Adam Malik berpendidikan D - III dengan rata - rata tingkat pengetahuan kurang tentang penularan HIV/AIDS pada proses persalinan sebanyak $51,4 \%$.

Dari hasil uji Chi-square diketahui nilai $p(0,35)$ $>0,05$, ini berarti tidak ada hubungan yang signifikan antara pendidikan dengan tingkat pengetahuan.

Hubungan Lama Bekerja Dengan Pengetahuan Bidan Tentang Penularan HIV/AIDS Pada Proses Persalinan

Hubungan lama bekerja dengan pengetahuan bidan tentang penularan HIV/AIDS pada proses persalinan dapat dilihat pada tabel sebagai berikut:

Tabel 7. Distribusi Lama Bekerja Berdasarkan Tingkat Pengetahuan Bidan Tentang Penularan HIV/AIDS Pada Proses Persalinan Di RSUP Haji Adam Malik Medan Tahun 2013

\begin{tabular}{|c|c|c|c|c|c|c|c|c|}
\hline \multirow{3}{*}{ No } & \multirow{3}{*}{$\begin{array}{l}\text { Lama } \\
\text { Bekerja }\end{array}$} & \multicolumn{4}{|c|}{ Pengetahuan } & \multirow{2}{*}{\multicolumn{2}{|c|}{-Total }} & \multirow{3}{*}{$\boldsymbol{P}$} \\
\hline & & \multicolumn{2}{|c|}{ Baik } & \multicolumn{2}{|c|}{ Kurang } & & & \\
\hline & & $\overline{\mathbf{F}}$ & $\%$ & $\mathbf{F}$ & $\%$ & $\mathbf{F}$ & $\%$ & \\
\hline 1. & $>10$ Tahun & 20 & 45,5 & 24 & 54,5 & 44 & 100 & \\
\hline 2. & $5-10$ Tahun & 4 & 40,0 & 6 & 60,0 & 10 & 100 & \\
\hline Jun & mlah & 24 & 44,4 & 30 & 55,5 & 54 & 100 & \\
\hline
\end{tabular}

Berdasarkan tabel 7 terdapat mayoritas bidan yang bekerja di RSUP H.Adam Malik dengan lama bekerja > 10 tahun dan rata - rata tingkat pengetahuan 
bidan tentang penularan HIV/AIDS pada proses persalinan kurang yaitu sebanyak 54,5\%.

Dari hasil uji Chi-square diketahui nilai $p(0,75)$ $>0,05$, ini berarti tidak ada hubungan yang signifikan antara lama bekerja dengan tingkat pengetahuan.

\section{Pembahasan}

Hubungan Umur Dengan Pengetahuan Bidan Tentang Penularan HIV/AIDS Pada Proses Persalinan

Dari hasil penelitian terhadap 54 orang bidan, diperoleh hasil uji chi-square tidak ada hubungan yang signifikan antara variabel umur dengan tingkat pengetahuan bidan tentang penularan HIV/AIDS pada proses persalinan. Berdasarkan hasil penelititan diperoleh mayoritas bidan berumur > 35 tahun sebanyak 43 orang $(79,6 \%)$ dan minoritas bidan berumur antara 25 - 35 tahun sebanyak 11 orang $(20,4 \%)$

Uji analisa bivariat diperoleh mayoritas bidan berumur $>35$ tahun dengan rata - rata tingkat pengetahuan kurang tentang penularan HIV/AIDS pada proses persalinan sebanyak $(55,8 \%)$. Dari hasil uji Chisquare didapat nilai $p(0,94)>0,05$, ini berarti tidak ada hubungan yang signifikan antara umur dengan tingkat pengetahuan.

Menurut Elisabeth BH dalam Nursalam (2003), usia adalah umur individu yang terhitung mulai saat dilahirkan sampai berulang tahun. Dari segi kepercayaan masyarakat seseorang yang lebih dewasa dipercaya dari orang yang belum dewasa.

Menurut asumsi peneliti bahwa golongan umur responden menunjukkan golongan umur produktif yaitu 25 - 35 tahun dan > 35 tahun. Dalam hal ini semakin tua umur seseorang maka tingkat pengetahuan seseorang semakin tinggi karena banyaknya pengetahuan yang didapat dari pengalaman hidup.Dan semakin cukup umur seseorang maka semakin matang tingkat kematangan dan kekuatan seseorang dalam berfikir dan belajar.

\section{Hubungan Pendidikan Dengan Pengetahuan Bidan Tentang Penularan HIV/AIDS Pada Proses Persalinan}

Dari hasil penelitian terhadap 54 orang bidan, diperoleh hasil bahwa tidak ada perbedaan yang signifikan antara variabel pendidikan dengan pengetahuan bidan tentang penularan HIV/AIDS pada proses persalinan. Berdasarkan hasil penelitian diperoleh mayoritas bidan berpendidikan D - III yaitu sebanyak 37 orang $(68,5 \%)$ dan minoritas bidan berpendidikan D - I sebanyak 17 orang $(31,5 \%)$.

Hasil uji bivariat terdapat mayoritas bidan yang bekerja di RSUP H.Adam Malik berpendidikan D - III dengan rata - rata tingkat pengetahuan tentang penularan HIV/AIDS pada proses persalinan kurang sebanyak 51,4\%. Hal ini disebabkan karena bidan kurang memahami tentang penularan HIV/AIDS pada proses persalinan, sehingga dengan kurangnya pengetahuan bidan terhadap HIV/AIDS akan beresiko tinggi terhadap terinfeksinya virus HIV/AIDS
Dari hasil uji Chi-square diketahui nilai $p(0,35)$ $>0,05$, ini berarti tidak ada perbedaan yang signifikan antara pendidikan dengan tingkat pengetahuan.

Menurut penelitian Resminarti (2002), pendidikan responden tidak mempengaruhi pengetahuan bidan tentang penularan HIV/AIDS pada proses persalinan.

Menurut asumsi peneliti bahwa tingkat pendidikan sangat mempengaruhi seseorang dan perilaku seseorang.Pada umumnya semakin tinggi tingkat pendidikan seseorang maka semakin mudah menerima informasi. Dengan demikian tingkat pengetahuan seseorang berkaitan dengan tingkat pendidikannya, khususnya untuk bidan yang berpendidikan D-III maka pada umumnya pengetahuan tentang penularan HIV/AIDS pada proses persalinan lebih tinggi dari pada bidan D-I.

\section{Hubungan Lama Bekerja Dengan Pengetahuan Bidan Tentang Penularan HIV/AIDS Pada Proses Persalinan}

Dari hasil penelitian terhadap 54 orang bidan, diperoleh hasil bahwa tidak ada perbedaan yang signifikan antara variabel lama bekerja dengan pengetahuan bidan tentang penularan HIV/AIDS pada proses persalinan. Berdasarkan hasil penelitian diperoleh mayoritas bidan dengan lama bekerja >10 tahun yaitu sebanyak 44 orang $(81,5 \%)$ dan minoritas bidan dengan lama bekerja 5 - 10 tahun sebanyak 10 orang $(18,5 \%)$.

Hasil uji bivariat terdapat mayoritas bidan yang bekerja di RSUP H.Adam Malik dengan lama bekerja > 10 tahun dan rata - rata tingkat pengetahuan bidan tentang penularan HIV/AIDS pada proses persalinan kurang yaitu sebanyak 54,5\%. Hal ini disebabkan karena bidan kurang mendapatkan informasi tentang penularan HIV/AIDS pada proses persalinan, sehingga dengan kurangnya pengetahuan bidan terhadap HIV/AIDS akan beresiko tinggi terhadap terinfeksinya virus HIV/AIDS kepada bidan serta dapat memberikan pemikiran yang negatif dan diskriminasi (perlakuan yang tidak adil) terhadap orang dengan HIV/AIDS sehingga bidan tidak akan melakukan VCT yang dapat mengakibatkan terjadinya pemun-duran terhadap pencegahan HIV/AIDS.

Dari hasil uji Chi-square diketahui nilai $p(0,75)$ $>0,05$, ini berarti tidak ada perbedaan yang signifikan antara lama bekerja dengan tingkat pengetahuan.

Menurut Handoko dan latif (2006), lama bekerja adalah suatu kurun waktu atau lamanya tenaga kerja itu bekerja di suatu tempat.Faktor - faktor yang mempengaruhi lama bekerja yaitu tingkat kepuasan kerja, lingkungan kerja, pengembangan karier dan kompensasi hasil kerja. Hal ini terkait dengan lama bekerja seorang bidan yaitu semakin lama bekerja maka semakin banyak pula pengetahuan dan pengalaman klinis seorang bidan tentang penularan HIV/AIDS pada proses persalinan.

Menurut asumsi peneliti bahwa lama bekerja responden yang relatif panjang (lama) dan memiliki pengalaman kerja yang cukup lama tidak 
mempengaruhi responden dalam pencegahan penularan HIV/AIDS pada proses persalinan.

\section{KESIMPULAN DAN SARAN}

\section{Kesimpulan}

1. Mayoritas bidan yang bekerja di RSUP H.Adam Malik Medan yaitu berumur > 35 tahun dengan tingkat pengetahuan kurang tentang penularan HIV/AIDS pada proses persalinan. Hal ini disebabkan karena bidankurang mendapatkan informasi tentang penularan HIV/AIDS pada proses persalinan, sehingga dengan kurangnya pengetahuan bidan terhadap HIV/AIDS akan beresiko tinggi terhadap terinfeksinya virus HIV/AIDS kepada bidan serta dapat memberikan pemikiran yang negatif dan diskriminasi (perlakuan yang tidak adil) terhadap orang dengan HIV/AIDS khususnya pada ibu yang akan bersalin.

2. Mayoritas bidan yang bekerja di RSUP H.Adam Malik berpendidikan D - III dengan rata - rata tingkat pengetahuan kurang tentang penularan

HIV/AIDS pada proses persalinan. Hal ini disebabkan karena bidan kurang memahami tentang penularan HIV/AIDS pada proses persalinan, sehingga dengan kurangnya pengetahuan bidan terhadap HIV/AIDS akan

beresiko tinggi terhadap terinfeksinya virus HIV/AIDS kepada bidan serta dapat memberikan pemikiran yang negatif dan diskriminasi (perlakuan yang tidak adil) terhadap orang dengan HIV/AIDS sehingga bidan tidak akan melakukan VCT yang dapat mengakibatkan terjadinya pemunduranterhadap pencegahan HIV/AIDS.

3. Mayoritas bidan yang bekerja di RSUP H.Adam Malik dengan lama bekerja > 10 tahun dan rata rata tingkat pengetahuan bidan kurang tentang penularan HIV/AIDS pada proses persalinan. Hal ini disebabkan karena bidan kurang mendapatkan informasi tentangpenularan HIV/AIDS pada proses persalinan, sehingga dengan kurangnya pengetahuan bidan terhadap HIV/AIDS akan beresiko tinggi terhadap terinfeksinya virus HIV/AIDS kepada bidan serta dapat memberikan pemikiran yang negatif dan diskriminasi (perlakuan yang tidak adil) terhadap orang dengan HIV/AIDS sehingga bidan tidak akan melakukan VCT yang dapat mengakibatkan terjadinya pemunduran terhadap pencegahan HIV/AIDS.

4. Dari hasil uji Chi-square tidak ada hubungan yang signifikan. Hal ini berarti antara umur, tingkat pendidikan dan lama bekerja tidak mempengaruhi tingkat penge-tahuan bidan tentang penularan HIV/AIDS.

\section{Saran}

Adapun saran - saran yang disampaikan yaitu :

1. Bagi Tenaga Kesehatan

Diharapkan kepada petugas kesehatan khususnya bidan yang bertugas di Rumah Sakit Umum Pusat H.Adam Malik Medan Tahun 2013, untuk meningkatkan pengetahuan tentang penularan HIV/AIDS agar tidak menjadi resiko tinggi terhadap terinfeksinya virus HIV/AIDS dantidak memberikan diskriminasi terhadap orang dengan HIV/AIDS sehingga tidak terjadinya pemunduran terhadap pencegahan HIV/AIDS serta dapat memberikan meningkatkan kewaspadaan universal (kewaspadaan yang dilakukan secara menyeluruh) yang bertujuan untuk mencegah kemungkinan terjadinya penularan HIV/AIDS dari pasien ke petugas kesehatan. Agar diadakan pelatihan-pelatihan tentang HIV/AIDS khususnya pada saat menolong persalinan.

2. Bagi Institusi Pendidikan

Disarankan bagi institusi pendidikanagar menyeleng-garakan seminar-seminar tentang proses penularan HIV/AIDS yang bertujuan untuk menambah wawasan mahasiswi dan disarankan kepada mahasiswi untuk membentuk kelompok KIP-KRR di institusi pendidikan yang bertujuan untuk mengetahui cara pencegahan HIV/AIDS.

3. Bagi Peneliti

Diharapkan kepada peneliti selanjutnya, agar lebih men-dapatkan hasil yang lebih maksimal lagi dari penelitian ini. Dengan melakukan penelitian terhadap sikap bidan dengan pengetahuan tentang penularan dan pencegahan HIV/AIDS pada proses persalinan.

\section{DAFTAR PUSTAKA}

Departemen Kesehatan RI, 2003. Pedoman Nasional Perawatan Dukungan dan Pengobatan bagi ODHA, Jakarta.

Kewaspadaan Universal di Pelaysanaan
Kesehatan, Jakarta.
2009. Data dan Statistik HIV - AIDS di Daerah dan Kota di Indonesia 2009.http://design.wordpress.com/2009/12/02/ data-statistik-hiv-aids-di-daerah-kota-diindonesia-2009/. Jakarta

Kementrian Kesehatan RI,2011.Profil Kesehatan Indonesia Tahun 2010. Kementrian Kesehatan Republik Indonesia.

Hutapea,R, 2011. AIDS \& PMS dan PERKOSAAN. Edisi II. Rineka Cipta, Jakarta.

IBI, 2006. Bidan Menyongsong Masa Depan. Cetakan VII. Jakarta.

Jamaluddin, 2009. Dokter,Perawat, dan Bidan Rentan HIVIAIDS.

http://www.pemkomedan.go.id/news detail.php?id=3156. 
Maryunani,A. 2009. Pencegahan Penularan HIV adari Ibu Ke Bayi Penatalaksanaan Di Pelayanan Kebidanan. Trans Info Media, Jakarta.

Notoadmojo, 2010. Metodologi Penelitian Kesehatan, Rineka Cipta, Jakarta.

2007. Kesehatan Masyarakat Ilmu dan Seni. Rineka Cipta. Jakarta.

Nursalam, 2011. Asuhan Keperawatan Pada Pasien Terinfeksi HIV. Salemba Medika, Jakarta.

Politeknik Kesehatan, 2006. Panduan Penyusunan KTI. Medan.
Prawirohardjo,S, 2007. Ilmu Kebidanan. Yayasan Bina Pustaka Sarwono Prawirohardjo. Jakarta.

Pusyansus RSUP HAM, 2013. Angka Kejadian HIV/AIDS pada kasus kehamilan dan persalinan tahun 2009 - 2011. Rumah Sakit Umum Pusat Haji Adam Malik. Medan.

Wawan.A, Dewi, M. 2010. Teori \& Pengukuran PENGETAHUAN, SIKAP, DAN PERILAKU MANUSIA. Nuha Medika. Yogyakarta.

Yusrawati, 2010. Diklat Biostatistika. Politeknik Kesehatan. Medan. 